\title{
前中央水座宣驗所 舉行山東全省漁業調查
}

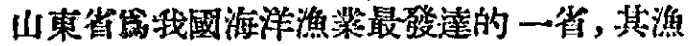
產量佔全國第一位。一兀五○年全國漁柴生產計 割, 以華東區生喾額佔首位,華東區則以山東省堬 重心。一儿五○年度, 本所重心工作,即配合此項 任移, 舉行山東全省漁蒋調查。筃地調查 全省各 重要漁區情况，俺便瞭解各漁區望况及其現保問 題，提供各珼漁籍基本統計資料，以備本年度生产 工作的參放，莎借一兀五一年度大力恢復山東省

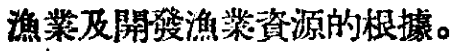

調查的重心有五:

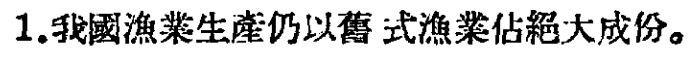
本調查的重心在霓式潐莱, 了解㴔村情

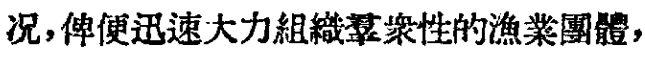
棈極扶持生产，使 其遭受連年戰争影響的 漁䅈低落情况，汛速恢復抗日戰爭前的生 就顀。

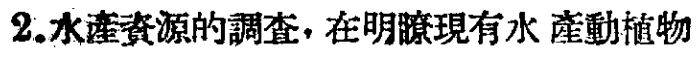

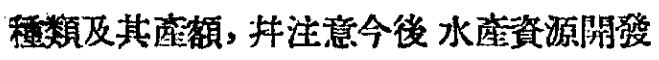
增殖及保護, 如昆布 (海帶)、裙帶茶、石花

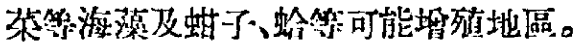

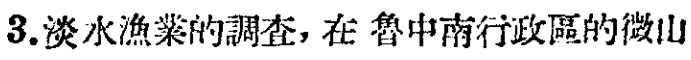

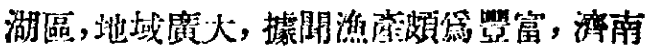

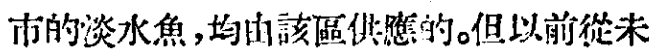
粘調查，今後注意其核區淡水焦㾞源的充

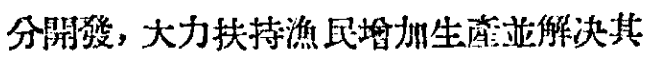
運銷問題。淡水䓹殖落調烃的重心擬在游

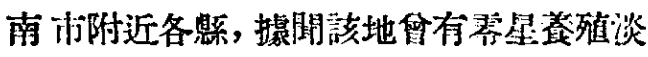

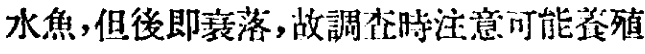
淡水围地區面皘，及其養殖時必须獬决的 困難問題。

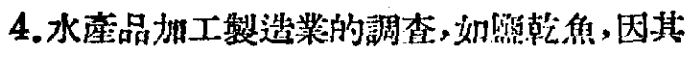

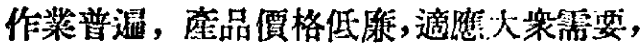

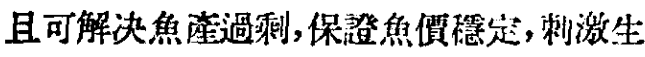
䄳。

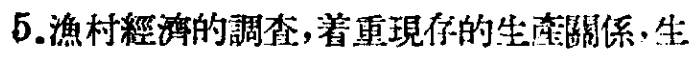

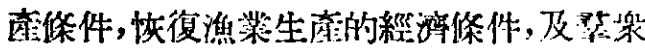
性漁莱組織,在塯 加焦奋的作用等。

(管振翡)

\section{前中央研究院化學研究所四月份工作報告}

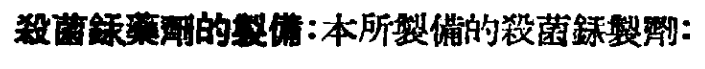
(一)乙基繁化䟿, 相虽於美國货“西力生”; (二)乙

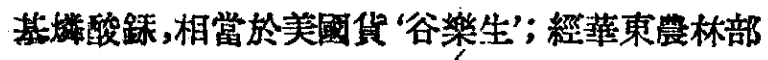
派員試驗，證明: 其對棉杍立枯病菌、炎疽病菌 和 紅病菌的生長抑制作用，和撲诚孢子的效用，均

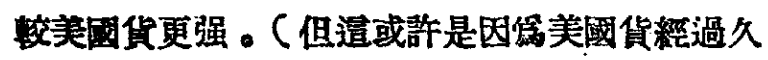
留,效力減低之故)現在工作，一方面，由華東農業 科異研究所進行田間薬效的比較試驗; 另一方面,

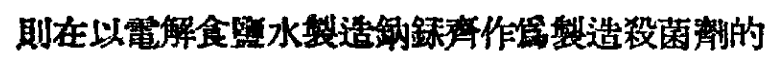
原料,使其成本诚低而便於大量生座。牛工成性試 正在計敖進行中。

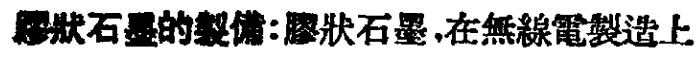
隹用很䈠。本所接受 華東工莱部的委託，代念製

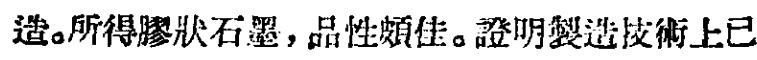
無問題。將來改進僅在能份膠跃球磨機 (colloidal

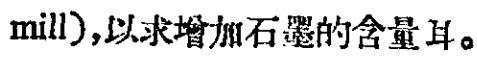

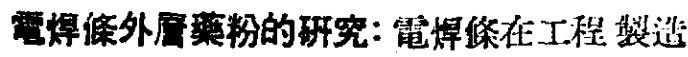
上,應用很廣。但其製造頝不容易。本所接受後勤

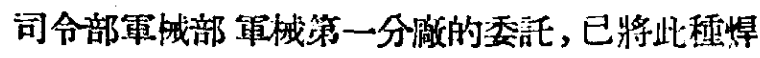
焂的外层桨粉與以詳細的分析, 結果知含缸、砤、

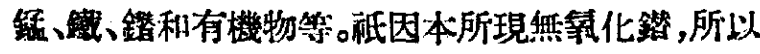
暫時末能仿造。

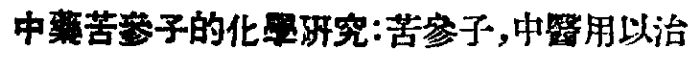
利。本所已在其中分得三種晶體物货。其中之一，

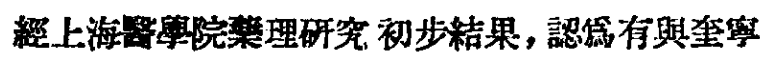
相似的治噳效能云。 (吳學周) 